\title{
Sweet sorghum-a local fodder with great potential
}

\author{
Chanda Nimbkar ${ }^{\dagger}$, Nandini Nimbkar and B. V. Nimbkar \\ Nimbkar Agricultural Research Institute, P.O. Box 23, 415523, Phaltan, Maharashtra, India
}

Sorghum (Sorghum bicolor L. Moench) is the fifth most important cereal crop in acreage and fourth most important in production in the world and is the dietary staple of more than 500 million people in 100 countries, primarily in the developing world. The grain is mainly used as animal feed in the developed world. Sorghum is mostly grown in the semi-arid tropics of the world under dryland conditions with low and erratic rainfall. Though it can survive on about $300 \mathrm{~mm}$ rainfall, it responds favourably to irrigation.

As much as 50\% of farmers' income from the sorghum crop in semi-arid tropics of India reportedly comes from the sale of the crop residue at urban fodder markets. In 2009 in India grain sorghum was planted on 7.7 million hectares and produced about 7.5 million tonnes of grain, with a low productivity of one-fourth that in the United States of America. Sorghum is also a good source of green fodder due to its quick growth, high yield and good quality. Therefore, grain sorghum is already being used as a dual-purpose crop in most areas of India.

Sorghum with sugar-rich juicy stalks (called sweet sorghum) is emerging as an important biofuel crop. Sweet sorghum has been studied for ethanol production and found to have lower crop production inputs of energy per litre of potential ethanol than sugar beet, fodder beet, corn and sugarcane. Canopy water use efficiency of sweet sorghum has been found to be higher than that of other $\mathrm{C}_{4}$ crops like maize and grain sorghum under both well-watered and water-stress conditions. However, though it is a well-known crop which can supply food, fodder, fiber and fuel it has not been studied much as a fodder crop.

Sweet sorghum probably differs from grain sorghum by only a few genes that control plant height and the presence of juice in stem and sugar in the juice. Substantial genotype variation has been reported to exist in fodder quantity and quality among different cultivars of sweet sorghum. There is plenty of genetic variation for all the component traits of sugar yield, stalk girth, days to $50 \%$ flowering and stalk-stover ratio. Also heritability is high for plant height, flowering time and test weight. Several brown mid-rib mutations have been reported in sweet sorghum which increase the digestibility of the plants by reducing the lignin content. Therefore breeders can manipulate the genes in the sweet sorghum plant to increase animal productivity provided specific breeding objectives are established. Use of molecular markers and quantitative trait loci are expected to enhance the efficiency and effectiveness of sweet sorghum improvement.

Sweet sorghum hybrids have been reported to produce higher sugar yield $(21 \%)$ and higher grain yield (15\%) than non-sweet sorghum hybrids in the rainy season indicating that there is no trade-off between grain and sugar. Even the quality of stover was often the best in genotypes with higher grain yields. The already standardized package of agronomic practices for grain sorghum can be applicable to sweet sorghum. However, improved region-specific agro-technology will have to be developed. Further improvement in sweet sorghum for livestock fodder needs to consider both qualitative and quantitative traits with collaborative work between sorghum breeders and livestock nutritionists.

\footnotetext{
${ }^{\dagger}$ E-mail: chanda.nimbkar@gmail.com
}

\section{Use of Acacia macrostachya Reichend. ex DC seeds as a source of protein in the diet of flesh chicken}

\author{
Valérie Marie Christiane Bougouma-Yaméogo ${ }^{1 \dagger}$, Seydou Ouattara ${ }^{1}$, \\ Charles Luanga Ouédraogo ${ }^{2}$ and Aimé Joseph Nianogo ${ }^{3}$
}

${ }^{1}$ Université polytechnique de Bobo Dioulasso. Institut de Développement Rural 01 BP 1091 Bobo Dioulasso Burkina Faso; ${ }^{2}$ Programme de Développement de I'Aviculture Villageoise 01 BP 1907 Ouagadougou 01 Burkina Faso; ${ }^{3}$ Union Mondiale pour la conservation de la nature, 01 BP 3133, Ouagadougou 01 Burkina Faso

\section{Aim}

The objective of the study was to determine conditions to use Acacia macrostachya seeds in the diet of flesh chicken.

\footnotetext{
† E-mail: bougouma_valerie@hotmail.com
} 